Kredo 4 (2020)
KREDO: Jurnal Ilmiah Bahasa dan Sastra
Terakreditasi Sinta 4 berdasarkan Keputusan Direktorat
Jenderal Penguatan Riset dan Pengembangan,
Kementerian Riset, Teknologi dan Pendidikan Tinggi
Republik Indonesia
Nomor: 23/E/KPT/2019. 08 Agustus 2019
https://jurnal.umk.ac.id/index.php/kredo/index

\title{
PENGGUNAAN PERMAINAN BAHASA DALAM PIDATO PEMILIHAN PRESIDEN 2019: STUDI KASUS PIDATO JOKOWI
}

\author{
Riza Alifianti Putri \\ rizaalifianty@gmail.com
}

Universitas Airlangga Surabaya, Indonesia

\section{Info Artikel Sejarah Artikel \\ Diterima \\ 26 Juni 2020 \\ Disetujui \\ 21 September 2020 \\ Dipublikasikan \\ 28 Oktober 2020}

\section{Keywords}

Language Game, Wittgenstein, Austin's Perspective, Jokowi's Speech

\section{Kata Kunci}

Permainan Bahasa, Wittgenstein,

Perspektif Austin, Pidato Jokowi

\section{Abstract}

The purpose of this article is to determine the use of language as a means of communication to reveal a meaning in political context. In addition, this article also aims to uncover people's insights and build a critical knowledge in an utterance to obtain sufficient understanding in determining a great leader for Indonesia. The theoretical basis used was the perspective of philosopher Ludwig Wittgenstein II combined with John Langshaw Austin's perspective. The research approach used was qualitative methods and case studies. The data sources were two speeches of Mr. Jokowi in the same context and continuous on 9-10 August 2018 taken from YouTube. Then, the authors used the orthographic transcription method in analysing the data. Furtherome, it can be concluded that language games are used in Jokowi's speech aiming to convince and gain public trust through the use of performative language, analogies, metaphors, as well as the formation of a person's identity, in this case Ma'aruf Amin as a vice presidential candidate.

\section{Abstrak}

Tujuan dari artikel ini adalah mengetahui penggunaan bahasa sebagai sarana berkomunikasi untuk mengungkap suatu makna dalam konteks politik. Selain itu, artikel ini juga bertujuan untuk membuka wawasan masyarakat serta membangun sikap kritis yang terkadung dalam sebuah ujaran sehingga memiliki pemahaman yang cukup untuk menentukan pemimpin untuk bangsa Indonesia. Landasan teori yang digunakan dalam penulisan artikel ini menggunakan pemikiran dari filsuf Ludwig Wittgenstein II dengan penambahan pemahaman melalui perspektif filsuf John Langshaw Austin. Pendekatan penelitian menggunakan metode kualitatif serta studi kasus. Data yang digunakan meliputi dua pidato Bapak Jokowi dalam konteks yang bersamaan dan berkesinambungan pada tanggal 09 Agustus 2018 dan pada tanggal 10 Agustus 2018 yang diambil melalui sumber situs YouTube (internet). Kemudian, penulis menggunakan metode transkripsi ortografis dalam pengolahan data dan menganalisisnya. Setelah proses analis selesai, dapat disimpulkan bahwa permainan bahasa digunakan dalam penyampaian pidato Jokowi yang bertujuan untuk meyakinkan dan memperoleh kepercayaan masyarakat melalui penggunaan bahasa performatif, analogi, metafora, dan pembentukan identitas seseorang yang dalam hal ini adalah Ma'aruf Amin sebagai calon wakil presiden.

\section{PENDAHULUAN}

Bahasa merupakan faktor yang penting dalam kehidupan manusia yang memiliki fungsi sebagai sarana berkomunikasi dan bertukar informasi dalam kehidupan sehari-hari. Hal ini memperlihatkan bahwa manusia memiliki hubungan yang sangat dekat dengan bahasa dimana bahasa merupakan suatu kunci manusia atas perannya sebagai makhluk sosial. Jika dibahas lebih dalam, bahasa tidak hanya sebuah rangkaian kata akan tetapi terdapat suatu makna didalamnya. Bahasa yang kita sampaikan merupakan sebuah kode atau sinyal seseorang untuk mengisyaratkan sesuatu, baik disampaikan melalui lisan, tulisan, atau media lainnya. Ketika kita berbicara, setiap kata yang diucapkan adalah suatu sistem atau kode (Utaker, 1992). Kode ini merupakan perantara manusia agar terciptanya suatu sistem komunikasi yang baik antara penutur dan pendengar. Hal serupa juga diungkap oleh Chaer

168 | Jurnal Kredo Vol. 4 No. 1 Oktober 2020 


Kredo 4 (2020)
KREDO: Jurnal Ilmiah Bahasa dan Sastra
Terakreditasi Sinta 4 berdasarkan Keputusan Direktorat
Jenderal Penguatan Riset dan Pengembangan,
Kementerian Riset, Teknologi dan Pendidikan Tinggi
Republik Indonesia
Nomor: 23/E/KPT/2019. 08 Agustus 2019
https://jurnal.umk.ac.id/index.php/kredo/index

(2015) bahwa bahasa merupakan alat untuk mengemukakan pikiran, ide, konsep kepada lawan bicara serta alat baik untuk mengajukan pertanyaan maupun perintah. Oleh karena itu, bahasa merupakan suatu hal yang krusial dalam perannya di kehidupan sehari-hari karena manusia akan mengalami kesulitan dalam memahami sesuatu tanpa bahasa.

Bahasa digunakan manusia dalam berbagai lini yang terdapat banyak variasi penggunaan bahasa. Tidak hanya digunakan sebagai sarana bertukar informasi, bahasa salah satunya juga digunakan dalam konteks politik. Dalam hal ini, bahasa digunakan sebagai sarana ajakan atau perintah untuk suatu kepentingan khusus dalam isu yang sedang dibahas di kalangan masyarakat. Selain itu, bahasa dalam konteks politik bertujuan untuk membentuk suatu identitas seseorang. Menurut Utaker (1992), bahasa yang dikeluarkan dalam tindak tutur menjelaskan identitas sesuatu sebagai kejadian dari beberapa konstanta umum atau invariant. Chaer (2015) juga menyebutkan bahwa bahasa juga digunakan sebagai penanda kenasionalan suatu bangsa, bahasa negara tersebut, serta bahasa pemersatu bangsa. Bahasa yang diujarkan dalam berbagai berbagai aspek, termasuk dalam konteks politik, tidak bisa disebut bahasa yang netral. Hal ini disebutkan dalam perspektif Wittgenstein bahwa bahasa yang digunakan dalam politik mengandung unsur permainan (Wilujeng, 2012). Hal tersebut memperlihatkan bahwa bahasa, dalam konteks politik khususnya, terkandung makna tersendiri untuk mendapatkan suatu kepentingan.
Berbicara lebih lanjut masalah politik, bahasa memiliki andil yang sangat penting dalam proses berkomunikasi yang memperhatikan bahwa bahasa merupakan sebuah media dalam komunikasi politik. Secara sederhana, politik dapat diartikan suatu bidang yang berkaitan dengan kekuasaan dan kepentingan bersama yang melahirkan sebuah sistem. Hal tersebut seperti yang disampaikan oleh Wilujeng (2012) bahwa secara alamiah muncul suatu sistem yang mengatur kepetingan bersama dalam kehidupan sehari. Cara berkomunikasi dalam politik juga dituntut untuk menggunakan bahasa yang baik agar tercapai sebuah maksud dan tujuannya. Pengunaan bahasa dalam berpolitik membutuhkan seni tersendiri agar dapat bermain lincah (Wilujeng, 2012). Dapat diartikan bahwa ujaran serta ungkapan yang terkandung harus memiliki pola yang baik untuk dapat meraih kepercayaan masyarakat masyarakat. Sehingga, dapat dipastikan bahwa bahasa-bahasa yang muncul dalam konteks politik mempunyai struktur dalam penempatan bahasanya sesuai dengan situasinya baik latar sosial ataupun latar kultural.

Dalam proses penyampaian bahasa, bahasa mengandung makna didalamnya yang juga mempunyai aturan-aturan yang tidak bisa dicampur satu sama lain. Pemikiran Wittgenstein mencetuskan bahwa bahasa memiliki bentuk logis dan tata bahasa logis dimana memiliki suatu permainan bahasa dan aturan-aturannya tersendiri (Utaker, 1992). Seperti contohnya, bahasa dalam pidato formal kebangsaan dengan bahasa dalam kehidupan sehari-hari memiliki perbedaan diksi yang digunakan bahkan 


Kredo 4 (2020)
KREDO: Jurnal Ilmiah Bahasa dan Sastra
Terakreditasi Sinta 4 berdasarkan Keputusan Direktorat
Jenderal Penguatan Riset dan Pengembangan,
Kementerian Riset, Teknologi dan Pendidikan Tinggi
Republik Indonesia
Nomor: 23/E/KPT/2019. 08 Agustus 2019
https://jurnal.umk.ac.id/index.php/kredo/index

pola yang berbeda. Sama halnya seperti bahasa dalam konteks ilmiah tidak bisa disamakan dengan ragam bahasa sastra atau santai karena mereka memiliki aturannya sendiri-sendiri (Chaer, 2015). Tidak menutup kemungkinan, terdapat pula permainan-permainan dalam penggunaan bahasa tersebut dalam konteks politik. Permainan tersebut sering dinamakan permainan bahasa atau yang biasa disebut language game.

Melihat maraknya isu politik yang beredar dalam kehidupan sehari-hari mengenai kebebasan demokrasi dan kebebasan hak menentukan pilihan, penulis melakukan penelitian pada kajian permainan bahasa yang ada dalam konteks politik. Hal ini dilakukan mengingat masyarakat adalah sasaran dalam permainan bahasa dimana memiliki peranan utama dalam penentuan keputusan Negara serta merupakan akses utama untuk meraih kekuasaan terutama dalam konteks politik. Disini dapat terlihat bahwa bahasa mempunyai andil yang cukup penting untuk membangun sebuah ideologi bangsa. Bahasa politik membawa ideologinya sendiri yaitu kepentingan penuturnya (Wilujeng, 2012). Hal ini berkaitan dengan sebutan bahwa tahun 2018 sebagai tahun politik dimana hampir seluruh bahasan-bahasan yang muncul dalam media adalah pengambilan atensi masyarakat dalam perolehan suatu kekuasaan, seperti contohnya pidato pemilihan presiden pada tahun 2019. Para calon presiden berkompetisi untuk menciptakan jargon, kampanye, dan deklarasi program kerja, jargon hingga melakukan pidato guna mendapat kepercayaan masyarakat. Secara tidak langsung, bahasa yang digunakan dalam pidato, ceramah, kampanye menyembunyikan sebuah kepentingan bagi pihak-pihak tertentu yang sangat menarik untuk dibahas. Oleh karena itu, artikel ini membahas bagaimana penggunaan permainan bahasa (language ame) milik Ludwig Wittgenstein periode kedua yang dilengkapi dengan perspektif John Langshaw Austin dalam pidato pemilihan presiden 2019 yang berfokus pada pidato Bapak Jokowi. Pidato beliau dirasa cukup menarik dikarenakan Bapak Jokowi yang telah menjadi presiden di periode sebelumnya ingin kembali mendapatkan suara dari masyarakat pada periode selajutnya.

Artikel ini juga bertujuan untuk mengetahui penggunaan bahasa sebagai sarana berkomunikasi untuk mengungkap suatu makna melalui permainan bahasa yang digunakan dalam kasus bahasa politik. Selain itu, artikel ini juga bertujuan untuk membuka wawasan masyarakat serta membangun sikap kritis untuk memahami maksud dari makna sebuah bahasa melewati pemahaman nilai-nilai yang terkadung dalam sebuah ujaran, terutama dalam konteks politik. Sehingga, masyarakat memiliki pemahaman yang baik dalam menentukan seorang pemimpin yang sesuai untuk menuju Indonesia yang lebih baik.

\section{KAJIAN TEORI}

\section{Konsep Permainan Bahasa}

Pada umumnya filsafat Wittgenstein (1889-1951) dibagi menjadi dua periode; Wittgenstein I dan Wittgenstein II (Kaelan, 2004). Periode pertama filsafatnya dikenal melalui 


Kredo 4 (2020)
KREDO: Jurnal Ilmiah Bahasa dan Sastra
Terakreditasi Sinta 4 berdasarkan Keputusan Direktorat
Jenderal Penguatan Riset dan Pengembangan,
Kementerian Riset, Teknologi dan Pendidikan Tinggi
Republik Indonesia
Nomor: 23/E/KPT/2019. 08 Agustus 2019
https://jurnal.umk.ac.id/index.php/kredo/index

karyanya Tractatus

Logico-

Philososphicus yang terkenal dalam teori gambar (Picture Theory) den menungkap logika bahasa. Dalam periode I Wittgenstein, ia mengemukakan mengenai struktur bahasa yang menganggap bahwa bahasa merupakan sebuah proposisi sederhana dan tidak terbatas serta menjelaskan bahwa makna dari sebuah proposisi adalah kenyataan yang seusai dengan fakta atau keberadaan peristiwa.

Dalam buku yang berjudul Philosophical Investigations, ia melakukan kritik pada pandangan pada periode sebelumnya dan melahirkan pemikiran Wittgenstein II. Dia menyatakan bahwa bahasa tidak hanya diperuntukkan untuk menggunakan proposisi-proposisi logis saja, melainkan dapat juga berfungsi sebagai peryataan, pembenaran, perintah, pengumuman, dan sebagainya. Pada periode ini, Wittgenstein mengemukakan pandangannya mengenai permainan bahasa dimana bahasa digunakan manusia dalam berbagai kehidupan manusia dan memiliki aturannya masing-masing.

Permainan bahasa mengungkapkan bahwa bahasa adalah salah satu bentuk aktivitas atau bentuk kehidupan manusia. Kris (1999) menjelaskan falsafah permainan bahasa secara ontologinya bahwa bahasa pada hakikatnya bergantung pada kehidupan manusia dengan hubungannya dengan pribadinya sendiri, masyarakat alam, dan terhadap Tuhan (dikutip dari Eswary, dkk., 2014). Dari aspek espistimologi terlihat bahwa bahasa memiliki aturan mainnya masingmasing, sedangkan aksiologi bahasa merupakan sarana berkomunikasi untuk menyampaikan ide, makna serta memberikan pemahaman sosial untuk memahami ungakapan bahasa tertentu.

Dalam permainan bahasa, arti dari kata bergantung kepada konteks penyampaian penuturnya atau meaning in use. Hal ini sesuai dengan pernyataan utama Wittgenstein II yaitu makna sebuah kata itu adalah penggunaannya dalam bahasa dan makna bahasa itu adalah penggunaannya dalam hidup (Chaer, 2015). Dari ungkapan tersebut dapat disimpulkan bahwa periode kedua Wittgenstein melibatkan aspek konteks (pragmatik) yang mempengaruhi penggunaan bahasa. Bahasa tersebut tidak akan berarti apa-apa jika ditempatkan pada kondisi yang bukan konteksnya. Hal ini dapat didasarkan pada pengertian umum bahwa makna sebuah kata adalah abstraksi sebuah objek. Dalam buku Philisophical Investigations, Wittgenstein menjelaskan bahwa permainan bahasa adalah suatu proses pemakaian kata, termasuk pula pemakaian bahasa yang sederhana. Setiap bentuk permainan bahasa memiliki ketentuan dan aturan sendiri yang tidak boleh dicampuradukkan, agar tidak menimbulkan kekacauan. Dengan demikian, arti yang terkandung dalam suatu kalimat tergantung pada pemakaiannya dalam bahasa.

Menurut Utaker (1992), pemainan bahasa membuktikan bahwa Wittgenstein dapat mempertajam perhatian manusia tentang bagaimana kita bisa melakukan banyak hal dengan kata-kata. Permainan bahasa ini dapat menimbulkan suatu tindakan peruasif dan juga hanya bisa menjelaskan informasi secara deskriptif saja. Disamping itu, menurut Eswary, dkk. 


Kredo 4 (2020)
KREDO: Jurnal Ilmiah Bahasa dan Sastra
Terakreditasi Sinta 4 berdasarkan Keputusan Direktorat
Jenderal Penguatan Riset dan Pengembangan,
Kementerian Riset, Teknologi dan Pendidikan Tinggi
Republik Indonesia
Nomor: 23/E/KPT/2019. 08 Agustus 2019
https://jurnal.umk.ac.id/index.php/kredo/index

(2014), dalam permainan bahasa terdapat pula metafora dan analogi (persamaan) merupakan strategi untuk mengungkapkan sesuatu dalam kehidupan kita sehari-hari dan dapat berintegrasi bukan hanya dalam bahasa melainkan juga fikiran dan perbuatan. Ara (2006) juga menyebutkan bahwa untuk menggambarkan sesuatu yang abstrak yang tidak dapat dijelaskan atau digambarkan secara langsung dengan menggunakan bahasa, maka Wittgenstein menggunakan strategi metafora dan analogi.

Menurut Wittgenstein, bahasa dalam kehidupan manusia penuh dengan keanekaragaman yang berbeda satu sama lain dan dalam konteks yang berda-beda (Chaer, 2015). Oleh karena itu, bahasa dalam konteks yang berbeda memiliki aturan-aturan mainnya masing-masing sehingga tidak bisa disamaratakan. Penggunaan bahasa juga harus disesuaikan dalam situasi dimana bahasa tersebut disampaikan. Apabila disimak lebih dalam seluruh ajaran Wittgenstein, terlihat bahwa filsafatnya tidak lain hanya menawarkan suatu metode, yang sering disebut sebagai metode analisis bahasa yang selaras dengan Kaelan (2004) yang menyebutkan bahwa seluruh pemikiran filsafat Wittgenstein hanyalah metode, yaitu critique of language (Baker, 1984: 125). Secara singkat, bahasa dapat digunakan sebagai sebuah metode atau caranya tersendiri di setiap konteks dan situasi.

Konsep lain mengenai permainan bahasa datang dari Austin, salah satu filsuf analitika bahasa, yang meneruskan pemikiran Wittgenstein. Dalam teori analitika bahasa biasa, ia membagi ujaran menjadi dua yaitu ujaran konstatif

172 | Jurnal Kredo Vol. 4 No. 1 Oktober 2020 dengan ujaran performatif (Chaer, 2015). Kedua bentuk ujaran tersebut memiliki perbedaan dalam hal tidak hanya dalam ujaran melainkan situasinya juga. Dalam buku Filsafat Bahasa (Chaer, 2015), ujaran konstatif adalah ujaran yang mengungkap atau mengatakan sesuatu seperti pernyataan dan deskripsi. Sedangkan ujaran performatif merupakan ujaran yang melakukan perbuatan atau tindakan seperti perjanjian, permintaan, dan permintaan. Ujaran performatif ditandai dengan penggunaan kalimat persona pertama (saya, aku, kami) bentuk indikatif, aktif, dan waktu sekarang.

Permainan bahasa juga merupakan penggunaan permainan bahasa yang dilakukan secara sederhana, praktis, dan tentunya deskriptif yang berisi informasi-informasi khusus didalamnya. Austin menjelaskan bahwa penggunaan bahasa tidak dapat dilepaskan dari situasi kongkret tempat mengemukakan ungkapan-ungkapan, dari fenomena yang berkaitan dengan bahasa tersebut (Chaer, 2015). Oleh karena itu, untuk menyempurnakan pemahaman dalam pembahasan topik artikel ini, diperlukan teori penggabungan antara pemikiran milik Wittgenstein dan Austin.

\section{Permainan Bahasa Dalam Konteks Politik}

Banyaknya isu politik yang menyebar di Indonesia menimbulkan sebuah penjelasan bahwa politik merupakan sebuah permainan yang membutuhkan bahasa sebagai sarana komunikasi. Dengan kata lain, terdapat pilihan bahasa tertentu pada konteks dan situasi yang digunakan dalam melakukan sebuah komunikasi (Wardhani, dkk, 


Kredo 4 (2020)
KREDO: Jurnal Ilmiah Bahasa dan Sastra
Terakreditasi Sinta 4 berdasarkan Keputusan Direktorat
Jenderal Penguatan Riset dan Pengembangan,
Kementerian Riset, Teknologi dan Pendidikan Tinggi
Republik Indonesia
Nomor: 23/E/KPT/2019. 08 Agustus 2019
https://jurnal.umk.ac.id/index.php/kredo/index

2018). Situasi yang dimaksud menyangkut dua hal yakni latar sosial dan latar kultural (Menurut Sholihatin (2008) dan Kholidah (2017) dikutip dari Wardhani, dkk, 2018). Yang dimaksud latar sosial disini ialah hal-hal yang mengarah pada sebuah nilai pada suatu ragam bahasa ketika digunakan dalam peristiwa tutur. Sedangkan, latar kultural disini berkaitan dengan nilai kesopanan dan pengetahuan penutur terhadap budaya pada suatu masyarakat tutur. Oleh karena itu, besar kemungkinan bahasa yang digunakan dalam konteks politik menggunakan sebuah permainan kebahasaan yang disesuaikan juga dengan situasi yang ada.

Menurut Wilujeng

(2012), penggunaan bahasa dalam politik dengan sendirinya merupakan sebuah permainan yang dapat dinamakan permainan bahasa. Segala aspek tindakan politik dipengaruhi oleh penggunaan bahasa dimana memiliki peran yang sangat penting terutama dalam berdemokrasi. Sugiharto (1996) juga menambahkan bahwa dalam demokrasi selalu membutuhkan retorika dimana hanya mendahulukan "efek" bukan isi hingga mengakibatkan keputusan yang ditentukan oleh penyalahgunaan pikiran (impetus animi) dari pada penalaran yang benar (recta ratione) (dikutip dari Wilujeng, 2012). Ia juga menyampaikan bahwa retorika tersebut memprioritaskan kemenangan daripada kebenaran, sehingga bahasa yang digunakan mempunyai efek persuasi yang berfungsi secara pragmatis untuk mempengaruhi pendengarnya.

Di antara beberapa sistem politik yang berjalan, sistem demokrasilah yang paling banyak menggunakan unsur permainan dalam penggunaan bahasa yang dalam istilah Wittgenstein permainan bahasa (Wilujeng, 2012). Ia juga menyampaikan bahwa diplomasi dan pembentukan persepsi merupakan sarana untuk memperlancar jalan mencapai tujuan. Oleh karena itu, hal ini menuntut kecakapan bahasa penuturnya. Dalam hal ini, sangat terlihat bahwa bahasa merupakan sarana media komunikasi dalam era demokrasi ini yang sangat penting untuk meyakinkan, mendapat simpati, serta mengambil hati khalayak ramai.

\section{Konsep Pidato}

Pidato bisa dikatakan sebagai alat penyalur aspirasi penutur kepada pendengar yang disusun menggunakan kaidah bahasa yang disesuaikan dengan konteks dan situasinya. Menurut KBBI, pidato merupakan sebuah pengungkapan pikiran dalam bentuk kata-kata yang ditujukan kepada orang banyak. Selain itu, Jupriono (2010) juga mengemukakan bahwa pidato yang berbentuk sebuah teks merupakan satu sistem tanda tergorganisasi yang merefleksikan sikap, keyakinan, dan nilai-nilai tertentu. Dalam hal ini, pidato merupakan salah satu bentuk penggalangan kekuasaan yang sangat lekat dengan kajian linguistik. Melalui penyampaian pidato, publik figur berusaha untuk menyalurkan aspirasi kepada khalayak umum. Dalam konteks politik, pidato dapat digunakan untuk membujuk masyarakat dengan kalimat-kalimat persuasinya guna mendapat atensi dari masyarakat. Selain itu, pidato juga digunakan sebagai salah satu metode yang sangat sering digunakan untuk menegakkan ideologi yang bertajuk pidato politik atau pidato kenegaraan. 


Kredo 4 (2020)
KREDO: Jurnal Ilmiah Bahasa dan Sastra
Terakreditasi Sinta 4 berdasarkan Keputusan Direktorat
Jenderal Penguatan Riset dan Pengembangan,
Kementerian Riset, Teknologi dan Pendidikan Tinggi
Republik Indonesia
Nomor: 23/E/KPT/2019. 08 Agustus 2019
https://jurnal.umk.ac.id/index.php/kredo/index

\section{METODE PENELITIAN}

Pendekatan penelitian yang digunakan dalam artikel ini menggunakan metode deskripsi kualitatif. Sebagaimana dinyatakan oleh Dörnyei (2007), pendekatan kualitatif lebih memperhatikan pada penggambaran, pemahaman, dan klarifikasi aspek pengalaman manusia yang idiosinkratik. Hal ini sesuai dengan pembahasan pidato pemilihan presiden dimana konteks yang ada dalam pidato adalah penjelasan sosok calon wakil presiden, Ma'ruf Amin. Selain itu, artikel ini termasuk studi kasus karena penulis hanya mengangkat pidato milik Jokowi saja dan tidak membahas mengenai pidato milik calon presiden lainnya. Dalam hal ini, penulis hanya mengambil konteks pidato Jokowi ketika deklarasi calon presiden untuk periode 2019 tanpa melihat pidato Jokowi lainnya. Hal ini berkesinambungan dengan Creswell (2003:51) yang menjelaskan bahwa studi kasus merupakan studi dimana peneliti mengeksplorasi secara mendalam program, acara, aktivitas, proses, atau satu atau lebih individu dan mereka dibatasi oleh waktu dan aktivitas.

Pada penelitian kali ini, penulis menggunakan dua data pidato Bapak Jokowi dalam konteks yang bersamaan dan saling berkaitan satu sama lain. Kedua Pidato tersebut berisikan mengenai pendeklarasian pasangan wakil presidennya kepada masyarakat pada bulan 09 Agustus 2018 sedangkan pidato kedua pada tanggal 10 Agustus 2018 yang diambil melalui sumber situs YouTube (internet). Kemudian, penulis menggunakan metode transkripsi ortografis dalam pengolahan data dan melakukan proses analisis. Data dalam proses analisis ditulis berdasarkan nomor data telebih dahulu (nomor 1 untuk pidato pertama sedangkan nomor 2 untuk pidato nomor 2), dan dilanjutkan dengan nomor ujaran. Penulis hanya menggunakan dua pidato tersebut dikarenakan kedua data pidato memiliki jumlah ujaran atau kallimat yang cukup. Pidato pertama memiliki 12 ujaran atau kalimat serta pidato kedua memiliki 24 ujaran atau kalimat. Hal ini sesuai dengan yang dinyatakan oleh Dörnyei (2007) bahwa penelitian kualitatif merupakan sebuah penelitian yang mendalam oleh karenanya sampel data yang digunakan dapat lebih kecil guna mendapatkan hasil yang lebih fokus dan terinci. Proses analisa dalam atikel ini menggunakan pemikiran gabungan dari Wittgenstein dan Austin untuk membentuk pemahaman yang utuh dalam pokok bahasan ini. Setelah proses analis selesai, penulis melakukan tahap interpretasi berdasarkan data yang diperoleh dan diikuti oleh simpulan hasil penelitian.

\section{HASIL DAN PEMBAHASAN}

Pada proses analisis, ditemukan bahwa permainan bahasa digunakan pada pidato Bapak Jokowi ketika pendeklarasian calon wakil presiden bulan Agustus 2019 lalu. Hal tersebut terlihat pada kalimat pembuka pada data pertama pada ujaran ke tiga, yang selanjutnya ditulis nomor data terlebih dahulu dan diikuti oleh nomor ujaran atau (1.3), yaitu:

"Setelah saya mendengarkan
masukan-masukan dari para

174 | Jurnal Kredo Vol. 4 No. 1 Oktober 2020 


Kredo 4 (2020)
KREDO: Jurnal Ilmiah Bahasa dan Sastra
Terakreditasi Sinta 4 berdasarkan Keputusan Direktorat
Jenderal Penguatan Riset dan Pengembangan,
Kementerian Riset, Teknologi dan Pendidikan Tinggi
Republik Indonesia
Nomor: 23/E/KPT/2019. 08 Agustus 2019
https://jurnal.umk.ac.id/index.php/kredo/index

ulama, ketua umum-ketua umum, ketua umum partai, seluruh pengurus, pengurus partai, dari relawan di seluruh Tanah Air dan tentunya aspirasi dari masyarakat luas, maka dengan mengucap Bismillahirrahmanirrahim, saya memutuskan untuk kembali mencalonkan diri sebagai Calon Presiden Republik Indonesia Periode 2019-2024."

Pada kalimat pembuka tersebut, terlihat bahwa bahasa sudah memiliki peran dalam perolehan dukungan untuk membuat keputusan yang dibuktikan dalam kalimat "setelah saya mendengarkan masukan-masukan dari para ulama, ketua umum-ketua umum....". Dalam kalimat tersebut terlihat bahwa keputusan yang dibuat sudah melalui proses perundingan dan demokrasi dengan pihak-pihak yang terlibat dibelakangnya dan tidak atas perumusan keputusan yang dilakukan sendiri. Pihak-pihak yang terlibat dalam perumusan keputusannya juga terlihat meyakinkan seperti para ketua umum lembaga dan juga partai. Selain itu, pengguanaan bahasa pada pidato pembukaan ini sebagai bukti untuk meyakinkan masyarakat bahwa Jokowi telah mendapat banyak masukan dan membuka peluang masyarakat untuk perpartisipasi dan ikut andil untuk kemajuan bangsa pada masa pemerintahannya. Disamping itu, penggunaan kata "bismillahirrahmanirrahim" digunakan pada awal pengumuman guna memperlihatkan bahwa konteks atau momen ini merupakan sebuah permulaan untuk hal yang baik setelah mendapat dukungan dari pihak-pihak yang telah disebutkan sebelumnya.

Setelah itu, kalimat pidato selanjutnya merupakan penyampaikan maksud dimana Jokowi mencalonkan diri untuk menjadi calon presiden. Melihat dari perspektif Austin, kalimat berikut termasuk dalam ujaran performatif yang dapat dilihat dalam kalimat "saya memutuskan untuk kembali mencalonkan diri sebagai Calon Presiden Republik Indonesia Periode 2019-2024". Ujaran tersebut merupakan tindak realisasi perbuatan atas dukungan-dukungan yang diperoleh dari berbagai pihak. Menurut Austin, tindakan performatif harus diucapkan oleh seseorang yang memiliki kompetensi untuk melakukan tindakan tersebut (Chaer, 2015). Hal ini sesuai dengan fakta bahwa Jokowi mempunyai kuasa dalam penyampaian ujaran tersebut dikarenakan beliau adalah pemimpin dalam pidato tersebut disamping beliau juga merupakan presiden yang sedang menjabat dalam periode ini dan memiliki peranan yang besar di Indonesia. Selain itu,

Setelah melakukan pembukaan, terdapat serangkaian isi yang disampaikan oleh Jokowi. Dalam isi pidato pertama ini, terdapat kalimat penegasan pada data 1.5, "Pada kesempatan ini, saya ingin menyampaikan keputusan sangat penting”. Kalimat ini mengindikasikan bahwa Jokowi telah menggunakan waktunya untuk memberikan informasi mengenai sesuatu hal yang penting pada masyarakat. Selain itu, penggunaan kata "sangat" disini mewakilkan kalimat penegasan bahwa informasi yang akan disampaikan merupakan sesuatu yang 


\begin{tabular}{|c|c|c|} 
Kredo 4 (2020) \\
KREDO: Jurnal Ilmiah Bahasa dan Sastra \\
Terakreditasi Sinta 4 berdasarkan Keputusan Direktorat \\
Jenderal Penguatan Riset dan Pengembangan, \\
Kementerian Riset, Teknologi dan Pendidikan Tinggi \\
Republik Indonesia \\
Nomor: 23/E/KPT/2019. 08 Agustus 2019 \\
https://jurnal.umk.ac.id/index.php/kredo/index
\end{tabular}

penting. Situasi ini juga berkaitan dengan waktu penyampaian dimana saat itu masyarakat menunggu keputusan Jokowi atas pemilihan presiden serta wakil presiden. Kemudian, isi pidato dilanjutkan dengan kalimat pada data 1.6 sampai 1.7:

"Setelah melalui perenungan
sangat dalam, dan dengan
mempertimbangkan masukan-
masukan, dan saran-saran dari
berbagai elemen masyarakat
seperti yang saya sebutkan pada
awal tadi."
"Maka, saya memutuskan dan
telah mendapatkan persetujuan
dari partai-partai koalisi yaitu
koalisi Indonesia Kerja, bahwa
yang akan mendampingi saya
sebagai calon wakil presiden
periode 2019-2024 adalah
Profesor Dr. KHMa'ruf Amin."

Pada data 1.6, terdapat pengulangan isi pidato tersebut juga menyampaikan bahwa adanya sebuah proses pemikiran yang matang hingga melahirkan sebuah keputusan. Dalam hal ini, terdapat permainan bahasa dalam pidato Jokowi yang lebih mengarah pada pengulangan penyampaikan dukungan oleh beberapa pihak terkait yang sudah disebutkan sebelumnya pada kalimat pembuka dalam penyampaiannya mencalonkan diri sebagai calon presiden RI 2019. Selain ujaran itu diikuti oleh perfomatif yang muncul dalam kalimat dalam data 1.7 "Maka, saya memutuskan dan telah mendapatkan persetujuan dari partaipartai koalisi...", terdapat pula penggunaan kata persona seperti penggunaan saya. Kata deiksis atau kata promina persona juga sering dijumpai dalam permainan bahasa (Chaer, 2015). Kemudian, terdapat pula penyampaian pesan bahwa calon wakil presiden yang dipilih merupakan pilihan bersama dengan partai koalisi Indonesia Kerja. Hal tersebut memperlihatkan permainan bahasa bahwa pemilihan wakil presiden dilandasi oleh dukungan-dukungan dan tidak merupakan kebijakan sepihak.

Mengingat banyaknya pro dan kontra atas keputusan Jokowi atas calon wakil presiden RI 2019, kalimat dalam data 1.8 "Mungkin ada beberapa pertanyaan dari masyarakat luas di seluruh tanah air, mengapa Profesor Dr KH Ma'ruf Amin yang dipilih", merupakan penyampaian kebenaran dan pengakuan bahwa memang ada keheranan masyarakat atas pilihan calon wakil presidennya. Dalam kalimat ini, terkandung pesan bahwa terdapat pandangan-pandangan yang dinilai masyarakat kurang sesuai atas keputusan Jokowi.

Akan tetapi dalam pidato ini, Jokowi mengungkap secara deskriptif secara singkat alasan pemilihan Ma'ruf Amin dalam kalimat di data 1.9 sampai 1.11:

Profesor Dr KH Ma'ruf Amin lahir di Tangerang, 11 Maret 1943, adalah sosok utuh, tokoh bijak, agama. Beliau duduk di legislatif, anggpta DPRD, DPR RI, MPR RI, Wantimpres, Rais Aam PBNU dan juga Ketua MUI (Majelis Utama Indonesia).

Dalam konteks ini, Jokowi berusaha memberi pandangan masyarakat dengan menyampaikan kredibilitas Ma'ruf Amin dalam bidang politik. Hal ini terbukti dalam kalimat "Beliau duduk di 


Kredo 4 (2020)
KREDO: Jurnal Ilmiah Bahasa dan Sastra
Terakreditasi Sinta 4 berdasarkan Keputusan Direktorat
Jenderal Penguatan Riset dan Pengembangan,
Kementerian Riset, Teknologi dan Pendidikan Tinggi
Republik Indonesia
Nomor: 23/E/KPT/2019. 08 Agustus 2019
https://jurnal.umk.ac.id/index.php/kredo/index

legislatif, anggota DPRD, DPR RI, MPR RI, Wantimpres, Rais Aam PBNU dan juga Ketua MUI (Majelis Utama Indonesia)". Dalam kalimat tersebut mengisyaratkan bahwa semua pertanyaan yang ada dalam benak masyarakat tidak perlu menjadi hal yang dikhawatirkan karena bukti-bukti kesusksesan Ma'ruf Amin yang tidak perlu dipertanyakan lagi. Penjelasan diatas menyimpulkan adanya penguatan bukti kemampuan Ma'ruf Amin yang didalamnya terdapat pula fungsi bahasa sebagai deskriptif bahwa kalimat tersebut merupakan pemberian informasi pernyataan pegumuman atas dipilihnya beliau sebagai pasangan calon presiden RI. Penjelasan melalui penggunaan bahasa yang amat rinci digunakan disini guna memberi gambaran baru atas sosok Ma'ruf Amin.

Dalam pidato kedua yang disampaikan oleh Jokowi, terdapat ungakapan-ungkapan penekanan atas terpilihnya Ma'ruf Amin sebagai calon presiden RI secara lebih terperinci. Beliau juga menyampaikan latar belajang Ma'ruf Amin yang bertujuan untuk meyakinkan masyarakat untuk tidak ragu atas pilihannya atas calon presiden RI 2019. Pidato kedua ini merupakan pidato lanjutkan deklarasi pemilihan Ma'ruf sebagai calon wakil presiden yang hanya selisih penyampaiannya satu hari saja. Pidato sebelumnya disamapaikan pada tanggal 09 Agustus 2018 sedangkan pidato kedua pada tanggal 10 Agustus 2018. Dalam pembukaan pidatonya pada data 2.3:

"Alhamdulillahirabil'alamin di pagi yang cerah ini, saya beserta bapak Profesor Kyai Haji Ma'ruf
Amin dari Gedung Joang 45 ini akan mendaftarkan diri menuju ke KPU."

Dalam kalimat tersebut, terdapat banyak bukti bahwa ujaran performatif mendominasi seperti adanya keterangan waktu sekarang pada kalimat di pagi yang cerah ini serta penggunaan kata persona saya pada kalimat saya beserta bapak Profesor Kyai Haji Ma'ruf Amin dari Gedung Joang 45 ini akan mendaftarkan diri menuju ke KPU. Kalimat tersebut juga menggunakan struktur kalimat aktif dimana kata saya disini adalah subjek yang berperan dalam melakukan sesuatu perbuatan. Dalam hal ini Jokowi yang melakukan kegiatan pendaftaran diri ke KPU dan terlibat langsung dalam melakukan aktivitas tersebut. Disini, Jokowi didampingi oleh Ma'ruf Amin dalam deklarasi tersebut yang juga bisa disebut perkenalan pada masyarakat dimana Jokowi pertama kali berdampingan dengan Ma'ruf Amin. Hal ini juga berkaitan dengan teori Austin bahwa ujaran performatif ditandai dengan penggunaan kalimat persona pertama (saya, aku, kami) bentuk indikatif, dan waktu sekarang (Chaer, 2015).

Dalam kalimat selanjutnya pada data $2.4-2.6$ :

"Di masa lalu, Gedung Joang 45 ini adalah tempat di mana para pejuang, pejuang politik kita, Bung Karno, Bung Hatta, Adam Malik, semuanya digembleng dari sisi politiknya."

"Gedung Joang 45 ini mewakili semangat perjuangan para pemuda yang menyala untuk 


Kredo 4 (2020)
KREDO: Jurnal Ilmiah Bahasa dan Sastra
Terakreditasi Sinta 4 berdasarkan Keputusan Direktorat
Jenderal Penguatan Riset dan Pengembangan,
Kementerian Riset, Teknologi dan Pendidikan Tinggi
Republik Indonesia
Nomor: 23/E/KPT/2019. 08 Agustus 2019
https://jurnal.umk.ac.id/index.php/kredo/index

merebut dan mempertahankan kemerdekaan."

"Kini Gedung Joang 45 kita pilih sebagai titik awal untuk memulai dalam perjuangan perjalanan perubahan untuk memenuhi dan mengisi kemerdekaan yang telah diperjuangkan oleh para pahlawan kita."

Jika dilihat dalam segi konteks, penggunaan bahasa dalam konteks deklarasi dengan berlatarkan Gedung Joang 45 merupakan pemilihan penempatan yang tepat. Sebelumnya, Jokowi menjelaskan kepada masyarakat bahwa Gedung Joang merupakan saksi bisu atas perjuangan pahlawan sebelumnya. Dalam kalimat tesebut, Jokowi menyampaikan secara jelas bahwa gedung ini dipilih sebagai awal mula perjuangan dimana melibatkan generasi muda untuk kemerdekaannya.

Kalimat tersebut juga mengisyaratkan bahwa gedung tersebut akan menjadi saksinya dalam terpilihnya beliau dalam pemilihan presiden 2019 dengan kolaborasinya dengan calon presiden barunya. Disini muncullah kalimat analogi memadankan pembangunan sejarah yang sama dengan pahlawan yang sebelumnya dengan mulainya perjuangan yang akan ia lakukan dalam pembangunan bangsa pada periode kepemimpinannya. Hal ini sesuai dengan penjelasan Eswary, dkk. (2014) bahwa metafora dan analogi (persamaan) merupakan strategi permainan bahasa untuk mengungkapkan sesuatu dalam kehidupan kita sehari-hari dan dapat berintegrasi bukan hanya dalam bahasa melainkan juga fikiran dan perbuatan.
Yang secara tidak langsung, hal tersebut juga merupakan kalimat ajakan untuk para remaja memilih Jokowi dalam perannya mendukung sejarah peratahanan remaja pada periode sebelumnya.

Keberlanjutan kalimat dalam pidato kedua ini merupakan inti maksud penyampaian deklarasi calon presiden dan calon wakil presiden yang dilakukan di Gedung Joang 45. Pidato kedua ini bertujuan untuk menghapus keraguan masyarakat untuk memilih Jokowi dan Ma'ruf amin sebagai pasangan presiden di periode mendatang. Akan tetapi, sebelumnya terdapat dua kalimat penekanan mengenai masa pemerintahan Jokowi dimana pada periode ini hingga 2019 beliau menjadi presiden Indonesia seperti pada data 2.7 dan 2.8:

"Perjalanan kami berdua disertai partai pendukung, pengusung, dan relawan ingin meneruskan jalan perubahan yang telah dimulai 4 tahun lalu yakni perjalanan menuju Indonesia maju."

"Dalam waktu empat tahun ini atas pertolongan, ridho, dan kuasa Allah yang Maha Kuasa kita telah meletakkan pondasi-pondasi yang kokoh bagi bangsa Indonesia untuk dapat bergerak maju, bergerak lebih cepat, bergerak lebih kuat lagi ke arah masa depan."

Selain terdapat kalimat pengulangan dalam meyakinkan masyarakat terhadap dukungan yang didapat dari pihak-pihak yang terlibat, beliau juga menjelaskan hasil kerja perkembangan negara saat pemerintahan Jokowi saat ini dan diikuti oleh kalimat pengharapan untuk dapat 


Kredo 4 (2020)
KREDO: Jurnal Ilmiah Bahasa dan Sastra
Terakreditasi Sinta 4 berdasarkan Keputusan Direktorat
Jenderal Penguatan Riset dan Pengembangan,
Kementerian Riset, Teknologi dan Pendidikan Tinggi
Republik Indonesia
Nomor: 23/E/KPT/2019. 08 Agustus 2019
https://jurnal.umk.ac.id/index.php/kredo/index

melanjutkan pembangunan bangsa yang dapat dilihat dari kalimat “....meneruskan jalan perubahan yang telah dimulai 4 tahun lalu yakni perjalanan menuju Indonesia maju”. Kalimat diatas menggambarkan buktibukti nyata yang telah dilakukan Jokowi dalam masa pemerintahannya guna membangun Indonesia maju.

Secara tidak langsung, Jokowi memberi sinyal kepada masyarakat bahwa terdapat banyak perubahan yang terjadi dan akan melanjutkan pengembangannya pada periode yang akan datang. Disini pula terdapat permainan bahasa dalam kalimat metafora yang dapat dilihat dari potongan kalimat meletakkan pondasipondasi yang kokoh yang diibaratkan sebagai perubahan besar yang telah dilakukan. Hal ini menimbulkan pandangan masyarakat bahwa perubahan-perubahan tersebut adalah alat untuk menjadikan pembangunan yang lebih kontinu yang terlihat dalam kalimat "untuk dapat bergerak maju, bergerak lebih cepat, bergerak lebih kuat lagi ke arah masa depan" dimana merupakan kalimat penegasan yang diulang guna lebih meyakinkan masayarakat. Permainan bahasa melalui penggulangan kata terlihat pada kalimat tersebut.

Pada data nomor $2.9-2.14$, Jokowi menyampaikan isi dari pidato ini guna memberikan pandangan terhadap masyarakat akan latar belakang dari Ma'ruf Amin, yang dapat dilihat sebagai berikut:

"Saya yakin Profesor Kyai Haji Ma'ruf Amin adalah figur yang tepat untuk mendampingi saya melanjutkan menempuh jalan perubahan itu. Beliau adalah sosok yang utuh, sosok yang utuh, ulama bijaksana, ulama yang dihormati oleh umat Islam di seluruh tanah air. Beliau memiliki pengalaman yang panjang di legislatif, di DPRD, di DPR, di MPR dan juga di eksekutif, di Watimpres dan di Dewan Pengarah BPIP. Serta, beliau adalah Rais Aam di PBNU dan Ketua Majelis Ulama Indonesia. Artinya beliau memiliki rekam jejak dan pengalaman yang lengkap, yang lengkap. Beliau memiliki pandangan yang sama dengan kita, dengan saya, bahwa sebagai negara dengan penduduk Muslim terbesar kita harus mengatasi masalah kemiskinan, masalah kesenjangan dengan memperkuat ekonomi umat di seluruh tanah air.

Pada kalimat tersebut terdapat pengulangan dalam penyampaian bahwa Ma'ruf adalah sosok yang beliau pilih yang disampaikan dalam kalimat performatif yang ditandai oleh "saya yakin...". Kalimat tersebut dapat menghasilkan suatu kepercayaan masyarakat hingga Jokowi mendapat suara dalam pemilihan presiden 2019. Selain itu, Jokowi memberikan pandangan mendalam atas sosok Ma'ruf Amin dan menyampaikan keunggulankeunggulannya. Seperti, ujaran yang mendandakan bahwa Ma'ruf yang merupakan tolak ukur agama islam yang baik untuk dijadikan panutan. Hal ini dapat dilihat dalam kalimat Beliau adalah sosok yang utuh, sosok yang utuh, ulama bijaksana, ulama yang 


\begin{tabular}{|c|c|c|} 
Kredo 4 (2020) \\
KREDO: Jurnal Ilmiah Bahasa dan Sastra \\
Terakreditasi Sinta 4 berdasarkan Keputusan Direktorat \\
Jenderal Penguatan Riset dan Pengembangan, \\
Kementerian Riset, Teknologi dan Pendidikan Tinggi \\
Republik Indonesia \\
Nomor: 23/E/KPT/2019. 08 Agustus 2019 \\
https://jurnal.umk.ac.id/index.php/kredo/index
\end{tabular}

dihormati oleh umat Islam di seluruh tanah air dan juga pada istilah Rais Aam di $P B N U$ dan perannya sebagai Ketua Majelis Ulama Indonesia. Dalam kalimat tersebut, terdapat pengulangan pada kalimat sosok yang utuh yang juga terdapat pada pidato pertamanya dimana ia menegaskan bahwa Ma'ruf Amin adalah pridabi agamis yang baik. Kalimat utuh merupakan kalimat sederhana yang digunakan dalam permainan bahasa ini untuk menyajikan maksud yang mendalam dari sebuah ujaran.

Selain itu, kredibilitas beliau dalam segi pemerintahan digambarkan untuk tidak perlu diragukan karena pengalaman dan sepak terjangnya yang cukup banyak seperti pengalaman di kursi DPRD, DPR dan sebagainya. Hal ini memperkuat maksud dan tujuan diadakannya pidato tersebut guna memberi penjelasan mendalam dan menggambarkan identitas sosok Ma'ruf Amin hingga dapat meraih kepercayaan masyarakat, yang merupakan pasangan barunya.

Jokowi juga menyampaikan dalam pidatonya bahwa Ma'ruf merupakan sosok yang mempunyai visi dan misi sama dengan pandangannya terhadap negara, seperti yang tersampaikan dalam kalimat (data 2.14): "Beliau memiliki pandangan yang sama dengan kita, dengan saya, bahwa sebagai negara dengan penduduk Muslim terbesar kita harus mengatasi masalah kemiskinan, masalah kesenjangan dengan memperkuat ekonomi umat di seluruh tanah air". Peggunaan kata kita disini mengindikasikan bahwa masyarakat terlibat dalam mempunyai pandangan yang sama dengan kedua calon pasangan

180 | Jurnal Kredo

Vol. 4 No. 1 Oktober 2020 presiden. Dan secara tidak langsung, Jokowi dan Ma'ruf akan mempunyai pemikiran yang sama dengan masyarakat dan dapat memahami lebih dalam pemikiran masyarakat luas. Dalam kalimat tersebut menjelaskan juga bahwa dibutuhkannya pergerakan bersama antara masyarakat dan kedua calon pasangan presiden untuk mengatasi problema yang terjadi di Indonesia.

Dalam pidato Jokowi, terdapat juga makna penggambaran citra untuk membentuk identitas seseorang, yang dalam hal ini adalah Ma'ruf Amin sebagai sosok akademisi yang baik. Hal ini terlihat dalam potongan pidato pada data $2.15-2.17$ :

Untuk diketahui, pada saat beliau dikukuhkan sebagai profesor, pidato pengukuhannya adalah berkaitan dengan arus ekonomi baru Indonesia. Artinya beliau sangat megetahui mengenai ekonomi juga. Bersama Kyai Haji Ma'ruf Amin kita ingin semuanya, saya ingin, tetap istiqomah untuk mewujudkan menuju Indonesia maju, Indonesia yang berdaulat, Indonesia yang mandiri, Indonesia yang berkepribadian.

Kalimat diatas menekankan bahwa Ma'ruf mempunyai kredibilitas bagus dalam ekonomi yang didukung penggunaan kata profesor disetiap panggilannya kepada Ma'ruf. Disini terlihat bahwa Jokowi membangun citra bahwa beliau memiliki kedudukan tertinggi dalam sebuah ilmu dengan kaitannya dengan masalah Negara. Penggunaan kata Kyai Haji juga dimunculkan oleh Jokowi jika konteks tersebut berhubungan dengan aspek 


Kredo 4 (2020)
KREDO: Jurnal Ilmiah Bahasa dan Sastra
Terakreditasi Sinta 4 berdasarkan Keputusan Direktorat
Jenderal Penguatan Riset dan Pengembangan,
Kementerian Riset, Teknologi dan Pendidikan Tinggi
Republik Indonesia
Nomor: 23/E/KPT/2019. 08 Agustus 2019
https://jurnal.umk.ac.id/index.php/kredo/index

agama. Hal tersebut membuat pandangan yang muncul bahwa Ma'ruf merupakan sosok yang layak dan pantas untuk mendampingi Jokowi dalam pemilihan presiden mendatang. Sebutan-sebutan tersebut sangat membuktikan adanya permainan kebahasaan yang digunakan untuk membangun citra seseorang.

Pada akhir pidato Jokowi (data 2.25) yang berbunyi "semoga Allah SWT selalu meridhoi perjalanan kita bersama, untuk mentransformasi Indonesia menuju negara yang maju". Jokowi kembali mengajak masyarakat dalam penggunaan kata kita untuk turut andil dalam perubahan bangsa. Dapat terlihat pemilihan kata juga berperan dalam melakukan deklarasi, seperti penggunaan kata mentransformasi. Kata tersebut digunakan dalam penyampaian pidato yang memiliki arti secara tatanan bahasa sebagai perubahan struktur dasar menjadi struktur lahir dengan menerapkan kaidah transformasi (KBBI). Melewati kata ini, dapat terlihat adanya perubahan besar yang melibatkan masyarakat dalam masa kepemimpinannya dalam periode mendatang.

Dari ulasan diatas, dapat dilihat pula bahwa permainan kata dalam penyampaian pidato calon pemilihan presiden ini menggunakan kata-kata yang sederhana akan tetapi bermakna mendalam. Hal ini sesuai dengan pokok bahasan dalam buku Philisophical Investigations (Kaelan, 2004), Wittgenstein menjelaskan bahwa permainan bahasa adalah suatu proses pemakaian kata, termasuk pula pemakaian bahasa yang sederhana. Penggunaan bahasa sederhana digunakan karena sasaran penyampaian pidato
Jokowi adalah seluruh lapisan masyarakat Indonesia. Bahasa sederhana digunakan agar mereka dapat memahami maksud dan tujuan dilangsungkannya pidato tersebut. Sehingga, tindakan yang dihasilkan dalam penggunaan bahasa bisa dilakukan sebagai hasil dari sebuah permainan. Hal ini sesuai dengan pendapat Utaker (1992) bahwa permainan bahasa ini dapat menimbulkan suatu tindakan peruasif dan juga hanya bisa menjelaskan informasi secara deskriptif saja. Melihat pentingnya peran masyarakat dalam kontribusinya pada pemilihan presiden 2019, pidato ini dibuat dengan tujuan tertentu seperti meraih kepercayaan serta meyakinkan masyarakat untuk mendapatkan suara agar terpilih menjadi presiden 2019. Hal ini sesuai dengan Wilujeng (2012) bahwa terdapat sebuah retorika bahasa yang digunakan dalam aspek politik yang memprioritaskan kemenangan sehingga bahasa yang digunakan mempunyai efek persuasi yang berfungsi secara pragmatis untuk mempengaruhi pendengarnya. Dalam hal ini, mempengaruhi untuk mendapat kemenangan dan kepercayaan masyarakat Indonesia terhadap keputusan yang diambil.

\section{SIMPULAN}

Dalam pembahasan tersebut, dapat ditarik kesimpulan bahwa permainan bahasa juga digunakan dalam konteks politik, dalam hal ini adalah pidato milik Jokowi dalam konteks pemilihan presiden 2019. Dalam perannya sebagai komunikasi politik, bahasa memiliki andil yang besar dalam kesuksesan menyampaikan ide dan tujuan 


\begin{tabular}{|c|c|c|} 
Kredo 4 (2020) \\
KREDO: Jurnal Ilmiah Bahasa dan Sastra \\
Terakreditasi Sinta 4 berdasarkan Keputusan Direktorat \\
Jenderal Penguatan Riset dan Pengembangan, \\
Kementerian Riset, Teknologi dan Pendidikan Tinggi \\
Republik Indonesia \\
Nomor: 23/E/KPT/2019. 08 Agustus 2019 \\
https://jurnal.umk.ac.id/index.php/kredo/index
\end{tabular}

pengujaran bahasa tersebut. Hal ini terlihat dalam analisis dalam pembahasan ini bahwa permainan bahasa digunakan untuk meyakinkan masyarakat dan mendapatkan kepercayaan masyarakat. Selain itu, terdapat makna dibalik pengungkapan pidato yang secara tidak langsung membuat masyarakat melakukan suatu tindakan. Dalam hal ini, pidato Jokowi berusaha untuk mendapatkan simpati dan atensi masyarakat untuk memilihnya sebagai calon presiden 2019. Dari penjelasan diatas membuktikan bahwa penggunaan permainan bahasa dalam politik mengisyaratkan bahwa terdapat makna dibalik penyampaian tuturan tersebut. Penjelasan diatas dapat disimpulkan pula bahwa bahasa memiliki pengaruh yang besar dalam kehidupan sehari-hari dan dalam berbagai konteks, dalam hal ini adalah konteks politik. Secara singkat, pidato Jokowi yang disampaikan mengandung permainan bahasa dengan menggunakan bahasa yang sederhana guna membentuk sebuah identitas atau memberi citra baru seseorang untuk meraih kepercayaan masyarakat.

Dalam kasus ini, ujaran performatif lebih mendominasi penyampaian maksud guna melibatkan langsung masyarakat dalam bagian sebuah pemerintahan serta memperoleh hasil atau tindak perbuatan atas pidato tersebut. Permainan bahasa analogi dan metafora juga dimainkan untuk menciptakan gambaran nyata dalam konteks tersebut. Selain itu, permainan bahasa juga digunakan untuk melukiskan citra seorang hingga membuat suatu identitas sesorang. Permainan bahasa yang dibangun oleh Jokowi juga meliputi pembentukan identas sosok pasangan baru calon presidennya yang digambarkan berdasarkan pengalamanpengalaman serta bukti kredibilitas yang dimiliki oleh Ma'ruf Amin.

\section{DAFTAR PUSTAKA}

Ara, Roshan. 2006. Wittgenstein's Concept of Language Games. Jurnal Al-Hikmat, 26: 47-62.

Asmara, Rangga. 2016. Strategi Kebahasaan Presiden Jokowi dalam Menanamkan Ideologi dan Manifesto Pemerintahan. LITERA, 15(2): 379-388.

Barker, A. 1984. Metode-metode Filsafat. Jakarta: Ghalia Indonesia.

Chaer, Abdul. 2015. FIlsafat Bahasa. Jakarta: Rineka Cipta.

Creswell, J. W. 2009. Research Design: Qualitative, Quantitative, and Mixed Methods Approaches (3rd ed.). Los Angeles: Sage Publications.

Dorney, Z. 2007. Research Method in Applied Linguistic: Quantitative, Qualititative, and Mixed Methodologies. Oxford: Oxford University Press.

182 | Jurnal Kredo Vol. 4 No. 1 Oktober 2020 


Kredo 4 (2020)
KREDO: Jurnal Ilmiah Bahasa dan Sastra
Terakreditasi Sinta 4 berdasarkan Keputusan Direktorat
Jenderal Penguatan Riset dan Pengembangan,
Kementerian Riset, Teknologi dan Pendidikan Tinggi
Republik Indonesia
Nomor: 23/E/KPT/2019. 08 Agustus 2019
https://jurnal.umk.ac.id/index.php/kredo/index

Eswary, E., Aman, R. 2014. Permainan Bahasa Wittgenstein: Kajian Leksikal Bahasa Melayu dan Indonesia. Melayu, 13.

Jupriono. 2010. Analisis Wacana Kritis Latar Historis dalam Pidato Kenegaraan Presiden Susilo Bambang Yudhoyono. Jurnal Parafrase, 10(2): 38-49.

Kamus Besar Bahasa Indonesia. 2008. Kamus dalam Jaringan. Jakarta: Kementerian Pendidikan dan Kebudayaan. Tanggal Akses 5 Oktober 2018.

Kaelan. 2004. Filsafat Analitis Menurut Ludwig Wittgenstein: Relevansinya bagi Perkembangan Pragmatik. Humaniora, 16 (2): 133-146.

Kholidah, Umi dan Haryadi. 2017. Wujud Pilihan Kode Tutur Mahasiswa Aceh pada Ranah Pergaulan di Semarang. SELOKA, 6(2): 208-217.

Kris, Budiman. 1999. Kosa Semiotika. Yogyakarta: LkiS.

Sholihatin, Anis. 2008. Pemilihan Kode pada Masyarakat Keturunan Arab di Noyontaan, Kota Pekalongan: Kajian Sosiolinguistik. Tesis: Universitas Diponegoro.

Sugiharto, Bambang. 1996. Postmodernisme: Suatu Tantangan dalam Filsafat. Yogyakarta: Kanisius.

Wardhani, dkk. 2018. Wujud Pilihan Bahasa dalam Ranah Keluarga pada Masyarakat Perumahan di Kota Purbalingga. Jurnal Kredo, 1(2): 91-105.

Wittgenstein, Ludwig. 1986. Philosophical Investigations. Diterjemahkan oleh G. Anscombe. Oxford: Blackwell Publisher Ltd.

Wilujeng, Sri Rahayu. 2012. Bahasa Politik dalam Perspektif Filsafat Bahasa Ludwig Wittgenstein. Humanika, 16 (9): 1-13.

Utaker, Arild. 1992. Form in Language: Wittgenstein and Structuralism. Wittgenstein and Contemporary Theories of Language Papers Edited by Paul Henry and Arild Utaker. Wittgenstein Archives: the University of Bergen. 